\title{
PERBEDAAN DUKUNGAN KELUARGA TERHADAP IBU YANG MEMBERIKAN ASI EKSKLUSIF DAN NON ASI EKSKLUSIF DI WILAYAH KERJA PUSKESMAS SUKORAME KECAMATAN MOJOROTO KOTA KEDIRI
}

\author{
(The Differences of Family Support Towards Mother who Breastfeed exclusively and Non- \\ exclusively in Puskesmas Sukorames’ Work Area Mojoroto District Kediri City)
}

Eny Sendra, Mika Mediawati, Amalia Afifi

Poltekkes Kemenkes Malang Prodi Kebidanan Kediri

\begin{abstract}
Exclusive breastfeeding has some benefits from some sides for the babies and their mothers. The intensity of exclusive breastfeeding at Puskesmas Sukorames' work area in Kediri is still low and need some efforts to increase it. The objective of this research is to know the differences of family support towards mother who breastfeed exclusively and non-exclusively in Puskesmas Sukorames' Work Area Mojoroto District Kediri City. This research used Retrospective approach and Case Control project which exclusive breastfeeding as the case and non-exclusive breastfeeding as the control group. Population used in this research were 335 exclusive breastfeeding respondents and 255 non-exclusive breastfeeding respondents by using Multi Stage Random Sampling was gotten 22 samples for exclusive breastfeeding and 11 samples for non-exclusive breastfeeding. Variable research was measured by a quisionaire consist of ten family supports. The result of Exact Fisher analysis was gotten $\mathrm{p}$ counted $=0,09$ and $\alpha=0,05$ ( $\mathrm{p}$ counted $>\alpha$ ) means $\mathrm{H}_{0}$ was accepted dan $\mathrm{Ha}$ was refused.The conclusion of this research was most of the respondent had high support to mother who breastfeed exclusively and the other most samples had low support to mother who breastfeed non-exclusively. So, there are no differences of family supports towards mother who breastfeed exclusively and non-exclusively in Puskesmas Sukorames' Work Area Mojoroto District Kediri City.
\end{abstract}

\section{Keywords:Exclusive Breastfeed, Family, Family Support, Mother.}

\section{PENDAHULUAN}

Bayi belum memiliki sistem percernaan yang sempurna sehingga jenis makanan yang dikonsumsi oleh bayi harus disesuaikan dengan kondisi tubuh bayi. ASI adalah sebuah cairan tanpa tanding ciptaan Allah untuk memenuhi kebutuhan gizi bayi dan melindunginya dalam melawan kemungkinan serangan penyakit, mengandung zat-zat gizi dalam air susu ibu dan berada pada tingkat terbaik apabila pemenuhan gizi ibu juga baik. ASI juga sangat kaya akan sari-sari makanan yang mempercepat pertumbuhan sel-sel otak dan perkembangan sistem syaraf. Makananmakanan tiruan untuk bayi yang diramu menggunakan teknologi masa kini tidak mampu menandingi keunggulan makanan ajaib ini. ASI mengandung sedikitnya seratus macam zat yang tidak terdapat dalam susu formula ( Departemen Kesehatan RI, 2011)

Pemberian ASI eksklusif dari berbagai segi akan sangat menguntungkan tidak hanya bagi bayi, tetapi juga bagi ibu. Dari sudut pandang psikologis, pemberian ASI merupakan suatu sarana pendekatan hubungan ibu dan bayi yang paling efektif. ASI eksklusif yaitu pemberian ASI saja sejak bayi dilahirkan sampai sekitar usia enam bulan dan selama itu tidak diharapkan mendapat tambahan cairan lain, seperti susu formula, air jeruk, air teh, madu, air putih dan dapat diteruskan hingga dua tahun (Maryunani, 2012). 
Menurut Nuryanti dkk (2009) terdapat beberapa faktor yang secara signifikan mempengaruhi pemberian ASI eksklusif, yaitu pengetahuan ibu tentang ASI eksklusif, dukungan suami dan keluarga, dan status pekerjaan ibu. Pada faktor dukungan, bentuk dukungan yang dinilai subjektif mempengaruhi proses pemberian ASI eksklusif adalah kemauan suami untuk berbagi pekerjaan rumah tangga saat ibu perlu menyusui atau istirahat, kepedulian suami akan asupan nutrisi ibu menyusui, kesediaan suami untuk menjadi tempat berbagi dan berkeluh kesah selama proses penyusuan, dan kesediaan suami untuk menemani saat ibu harus menyusui malam hari. Sumber dukungan lain, seperti ibu, ayah, bidan, dokter, dan saudara dipersepsikan sebagai sumber informasi dan nasihat untuk menguatkan motivasi ibu memberikan ASI eksklusif. Sumber dukungan utama suami $(97,7 \%)$, dukungan ibu kandung menduduki posisi kedua $(75 \%)$ disebabkan ibu adalah sumber informasi ketika mendapat masalah dalam menyusui dan ibu kandung lebih berpengalaman karena sudah menyusui berkali-kali, diikuti oleh dukungan tenaga kesehatan $(52,3 \%)$ dan dokter $(45,5 \%)$, saudara dan ibu mertua sama posisinya $(36,4 \%)$, dan terakhir ayah mertua $(25 \%)$.

Menurut Barra, Santander, \& Victoriano dalam Nuryanti (2009), perempuan yang tidak memiliki suami memiliki risiko yang lebih tinggi untuk menghentikan lebih awal pemberian ASI eksklusif daripada perempuan yang bersuami. Hal ini menunjukkan peran suami sebagai pemberi dukungan dalam proses menyusui sangatlah penting. Shi, et. al dalam Nuryanti (2009) menyatakan bahwa dukungan sosial dari orang-orang terdekat sangat mempengaruhi pemberian ASI secara penuh. Bentuk dukungan paling banyak berupa nasihat, pemberian informasi, dan kemauan keluarga untuk mengingatkan ibu dalam proses menyusui, juga keikutsertaan suami seperti ikut bangun dan menemani saat malam ibu harus menyusui, menyediakan susu untuk ibu, membantu pekerjaan rumah saat ibu menyusui, menyediakan diri untuk berbagi dan mendengarkan saat ibu memerlukan dukungan. Dukungan ibu dan ibu mertua menyediakan masakan dan sayuran yang mendukung ketersediaan ASI dalam jumlah yang cukup, mengingatkan ibu saat harus menyusui, dan menyiapkan baju ibu menyusui. Dukungan dari petugas kesehatan hanya berupa nasihat dan informasi, sementara keluarga ibu hampir semua disebutkan membantu ibu dalam proses menyusui.

Perhatian dan limpahan kasih sayang keluarga kepada ibu dan bayi, turut menentukan kadar emosi kebahagiaan ibu. Keluarga turut menemani saat ibu bangun malam untuk menyusui, mengganti popok, mengambilkan minum, atau mengambilkan makan setelah menyusui. Hal-hal tersebut akan mendorong refleks kimiawi tubuh untuk terus memproduksi ASI. Dukungandukungan tersebut otomatis akan memberikan motivasi tersendiri kepada ibu untuk memberikan ASI eksklusif (Eveline, 2010).

Masih banyak mitos yang beredar di masyarakat dan memengaruhi persepsi ibu tentang menyusui diantaranya, ibuibu beranggapan bahwa menyusui mengakibatkan bentuk tubuh ibu sukar kembali ke bentuk aslinya yang langsing dan berpikiran bahwa ASI tidak mencukupi kebutuhan nutrisi bayi karena bayi sering menangis (Riksani, 2012). Ibu yang bekerja di luar rumah tidaklah mudah karena kerepotan membagi waktu apabila bayi dirasa masih lapar jika tidak diberi tambahan susu formula. Untuk itu, keberhasilan pemberian ASI secara eksklusif ditentukan oleh peran keluarga. Selama proses pemberian ASI berlangsung, peran keluarga yang paling utama adalah menciptakan suasana dan situasi kondusif yang memungkinkan pemberian ASI berjalan dengan lancar. 
Dalam perannya, keluarga sebagai penghubung ibu dalam menyusui bayinya dengan membawa bayi kepada sang ibu saat ia lapar. Dengan demikian, ibu merasa tidak terbebani dan tidak merasa mengurus sendiri bayinya.

Berdasarkan studi pendahuluan telah diperoleh data jumlah bayi yang diberikan ASI eksklusif di wilayah Puskesmas dan Kecamatan Kota Kediri tahun 2012, pencapaian ASI eksklusif tertinggi adalah Puskesmas Pesantren I Kecamatan Pesantren (82,70\%) dan terendah Puskesmas Sukorame Kecamatan Mojoroto (29,44\%) (Dinas Kesehatan Kota Kediri, 2012). Permasalahan ASI eksklusif di wilayah Puskesmas Sukorame sangat jauh dari target pencapaian tahun 2012 yakni $70 \%$. Hal inilah yang mendorong peneliti untuk melakukan penelitian mengenai Perbedaan Dukungan Keluarga terhadap Ibu yang Memberikan ASI Eksklusif dan Non-ASI Eksklusif di Wilayah Kerja Puskesmas Sukorame Kecamatan Mojoroto Kota Kediri.

\section{METODE PENELITIAN}

Penelitian ini menggunakan desain penelitian Case Control yang bertujuan untuk menganalisa suatu penelitian analitik yang menyangkut bagaimana faktor risiko dipelajari dengan menggunakan pendekatan Retrospective (Notoatmodjo, 2010). Rancangan Case Control dilakukan dengan cara membandingkan dua kelompok, kelompok kasus dan kelompok kontrol. Penelitian ini menggunakan ASI eksklusif sebagai kelompok kasus, dan non ASI eksklusif sebagai kelompok kontrol.

\section{HASIL PENELITIAN}

Hasil pengumpulan data yang dilaksanakan pada tanggal 2-16 Juni 2014 di Wilayah Kerja Puskesmas Sukorame Kota Kediri didapatkan 33 responden yang digunakan sebagai sampel penelitian dan dari hasil pengumpulan data didapatkan hasil sebagai berikut :

\section{Data Umum}

1. Umur

Berikut tabel distribusi umur responden penelitian :

Tabel 1. Distribusi Responden menurut umur

\begin{tabular}{lcc}
\hline $\begin{array}{l}\text { Umur } \\
\text { (tahun) }\end{array}$ & $\begin{array}{c}\text { Responden } \\
\text { (orang) }\end{array}$ & Persentase \\
\hline $21-30$ & 11 & $33 \%$ \\
$31-40$ & 2 & $7 \%$ \\
$41-50$ & 7 & $21 \%$ \\
$51-60$ & 13 & $39 \%$ \\
\hline Jumlah & 33 & $100 \%$ \\
\hline
\end{tabular}

Berdasarkan data dari tabel di atas dapat disimpulkan bahwa kelompok umur responden terbanyak yaitu responden berumur 51-60 tahun sebanyak 13 responden dengan persentase $39 \%$.

\section{Pekerjaan}

Berikut tabel distribusi pekerjaan responden penelitian

Tabel 2. Distribusi Responden menurut pekerjaan

\begin{tabular}{lcc}
\hline Pekerjaan & $\begin{array}{c}\text { Responden } \\
\text { (orang) }\end{array}$ & $\begin{array}{c}\text { Persentase } \\
(\%)\end{array}$ \\
\hline IRT & 19 & $58 \%$ \\
Buruh & 4 & $12 \%$ \\
Pensiun & 3 & $9 \%$ \\
Swasta & 5 & $15 \%$ \\
Wiraswasta & 2 & $6 \%$ \\
& & \\
\hline \multicolumn{1}{c}{ Jumlah } & 33 & $100 \%$ \\
\hline
\end{tabular}

Berdasarkan data dari tabel di atas dapat disimpulkan bahwa sebagian besar responden tidak bekerja atau sebagai ibu rumah tangga (IRT) sebanyak 19 orang dengan persentase $58 \%$.

3. Pendidikan

Berikut tabel distribusi pendidikan responden ASI eksklusif 
Tabel 3. Distribusi pendidikan responden ASI eksklusif

\begin{tabular}{lcc}
\hline Pendidikan & $\begin{array}{c}\text { Responden } \\
\text { (orang) }\end{array}$ & Persentase \\
\hline SD & 7 & $32 \%$ \\
SMP & 7 & $32 \%$ \\
SMA & 7 & $32 \%$ \\
PT & 1 & $4 \%$ \\
\hline \multicolumn{1}{c}{ Jumlah } & 22 & $100 \%$ \\
\hline
\end{tabular}

Berdasarkan data dari tabel di atas dapat disimpulkan bahwa pendidikan pada responden ASIeksklusif berpendidikan SD, SMP, dan SMA masing-masing sebanyak 7 responden dengan persentase $32 \%$ dan hanya 1 responden yang berpendidikan Perguruan Tinggi dengan persentase $4 \%$.

Berikut tabel distribusi pendidikan responden non-ASI eksklusif

Tabel 4. Distribusi pendidikan responden non-ASI eksklusif

\begin{tabular}{lcc}
\hline Pendidikan & $\begin{array}{c}\text { Responden } \\
\text { (orang) }\end{array}$ & Persentase \\
\hline SD & 5 & $45 \%$ \\
SMP & 5 & $45 \%$ \\
SMA & 1 & $10 \%$ \\
\hline \multicolumn{1}{c}{ Jumlah } & 11 & $100 \%$ \\
\hline
\end{tabular}

Berdasarkan data dari tabel di atas dapat disimpulkan bahwa pendidikan pada responden non-ASIeksklusif berpendidikan SD dan SMP masingmasing sebanyak 5 responden dengan persentase $45 \%$ dan hanya 1 yang benpendidikan SMA dengan persentase $10 \%$.

\section{Data dukungan keluarga terhadap ibu yang memberikan ASI eklsklusif}

Berikut diagram dukungan keluarga terhadap ibu yang memberikan ASI eksklusif.
Diagram 1. Dukungan keluarga terhadap ibu yang memberikan ASI eksklusif

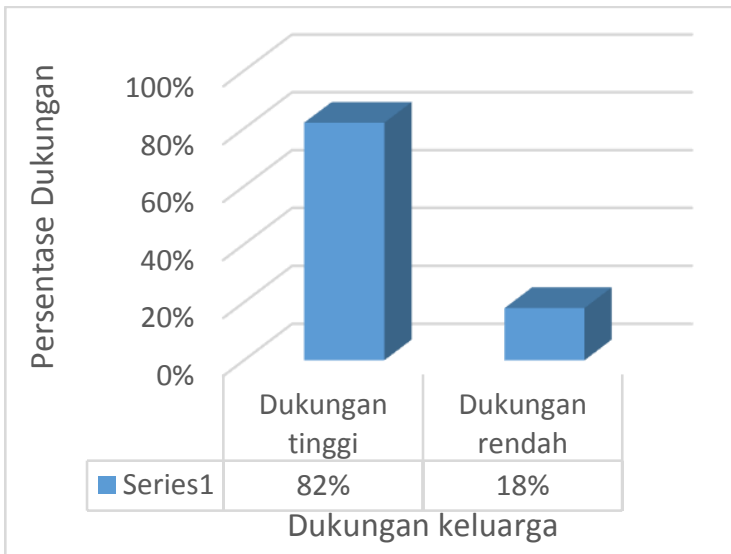

Berdasarkan diagram di atas dapat disimpulkan bahwa hampir seluruh responden yaitu dari 22 responden, 18 diantaranya dengan persentase $82 \%$ mempunyai dukungan tinggi terhadap ibu yang memberikan ASI eksklusif.

\section{Data dukungan keluarga terhadap ibu yang memberikan non-ASI eklsklusif}

Berikut diagram dukungan keluarga terhadap ibu yang memberikan non-ASI eksklusif.

Diagram 2. Dukungan keluarga terhadap ibu yang memberikan nonASI eksklusif

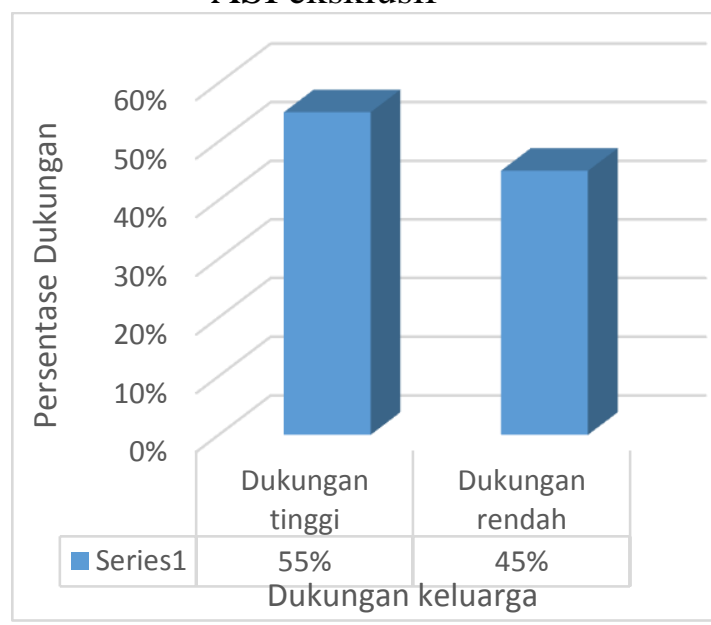

Berdasarkan diagram di atas dapat disimpulkan bahwa sebagian besar responden yaitu 6 dari 11 responden mempunyai dukungan tinggi terhadap ibu yang memberikan non-ASI eksklusif dengan persentase $55 \%$. 


\section{Hasil Uji Statistik}

Berdasarkan hasil penelitian didapatkan hasil perbedaan dukungan keluarga terhadap ibu yang memberikan ASI eksklusif dan non-ASI eksklusif sebagai berikut:

Tabel 5. Tabel silang dukungan keluarga dan status pemberian ASI

\begin{tabular}{|l|c|l|c|}
\hline $\begin{array}{l}\text { Dukungan } \\
\text { Status } \\
\text { pemberian } \\
\text { ASI }\end{array}$ & Tinggi & Rendah & Total \\
\hline $\begin{array}{l}\text { Eksklusif } \\
\text { Non } \\
\text { Eksklusif }\end{array}$ & $\begin{array}{l}18(\mathrm{a}) \\
6(\mathrm{c})\end{array}$ & $\begin{array}{l}4(\mathrm{~b}) \\
5(\mathrm{~d})\end{array}$ & $\begin{array}{l}22(\mathrm{a}+\mathrm{b}) \\
11(\mathrm{c}+\mathrm{d})\end{array}$ \\
\hline Total & $\begin{array}{c}24 \\
(\mathrm{a}+\mathrm{c})\end{array}$ & $9(\mathrm{~b}+\mathrm{d})$ & $33(\mathrm{~N})$ \\
\hline
\end{tabular}

$$
\begin{aligned}
\mathrm{fh}_{(\mathrm{a})} & =22 \times 24 / 33=16 \\
\mathrm{fh}_{(\mathrm{b})} & =22 \times 9 / 33=6 \\
\mathrm{fh}_{(\mathrm{c})} & =11 \times 24 / 33=8 \\
\mathrm{fh}_{(\mathrm{d})} & =11 \times 9 / 33=3
\end{aligned}
$$

Persyaratan uji Chi Kuadrat tidak memenuhi, bila nilai harapan (fh) kurang dari 5, sebaiknya Chi Kuadrat tidak digunakan karena dapat menimbulkan taksiran yang berlebihan, maka dapat digunakan uji Fisher Exact.

Rumus uji statistik Fisher Exact:

$$
\begin{gathered}
P=\frac{(A+B) !(C+D) !(A+C) !(B+D) !}{N ! A ! B ! C ! D !} \\
P=\frac{22 ! 11 ! 24 ! 9 !}{33 ! 18 ! 4 ! 6 ! 5 !}
\end{gathered}
$$

Dari hasil uji statistik dengan Fisher Exact didapatkan nilai $\mathrm{p}=0,09$ dan nilai ini lebih besar dari $\alpha=0,05$. Dengan ketentuan bila nilai $\mathrm{p} \geq \alpha$. Maka $\mathrm{H}_{0}$ diterima, artinya tidak adaperbedaan dukungan keluarga terhadap ibu yang memberikan ASI eksklusif.

\section{PEMBAHASAN}

\section{Dukungan Keluarga terhadap Ibu yang Memberikan ASI Eksklusif}

Dari hasil penelitian yang dilakukan kepada 22 responden didapatkan sebanyak 18 responden (82\%) memiliki dukungan tinggi terhadap pemberian ASI eksklusif. Sedangkan 4 responden (18\%) memiliki dukungan rendah terhadap pemberian ASI eksklusif. Hal ini menunjukkan kepedulian keluarga tinggi terhadap tercapainya ASI eksklusif sehingga sejalan dengan penelitian Anggorowati (2011), menyatakan dukungan keluarga sangat berperan dalam kelancaraan proses menyusui dan pemberian ASI. Semakin tinggi dukungan, semakin tinggi pula tercapainya ASI eksklusif.

Dukungan keluarga dipengaruhi beberapa faktor, yaitu faktor internal dan eksternal. Beberapa faktor internal yang mempengaruhi dukungan yaitu pengetahuan, pengetahuan dipengaruhi oleh umur, pendidikan dan pekerjaan, sedangkan faktor eksternal meliputi tradisi dan kepercayaan masyarakat terhadap hal-hal yang berkaitan dengan kesehatan, sistem nilai yang dianut masyarakat, tingkat sosial ekonomi, dan sebagainya. Faktor-faktor pemungkin yang mencakup ketersediaan sarana dan prasarana atau fasilitas kesehatan bagi masyarakat. Faktor penguat yang meliputi faktor petugas kesehatan, suami dalam memberikan dukungannya kepada ibu dalam merawat bayi (Notoatmojdo, 2010 ).

Peneliti berpendapat bahwa pengetahuan sangat erat hubungannya dengan pendidikan tinggi dan rendah, karena dengan pendidikan yang tinggi orang tersebut akan semakin luas pengetahuannya, tetapi bukan berarti seseorang yang berpendidikan rendah mutlak berpengetahuan rendah. Hal ini dikarenakan untuk meningkatkan pengetahuan tidak mutlak diperoleh dari pendidikan formal saja, tetapi dapat diperoleh melalui pendidikan nonformal (Wawan dan Dewi, 2010). Pengetahuan didapatkan dari kehidupan sehari-hari dimana pengetahuan tersebut belum jelas kebenarannya yang menyebabkan salah pengertian dan persepsi sehingga tujuan 
untuk mendapatkan ASI eksklusif tidak tercapai.

\section{Dukungan Keluarga terhadap Ibu yang Memberikan Non-ASI Eksklusif}

Dari hasil penelitian yang dilakukan kepada 11 responden didapatkan sebanyak 6 responden (55\%) memiliki dukungan tinggi terhadap pemberian ASI eksklusif, sedangkan 5 responden (45\%) memiliki dukungan rendah terhadap pemberian ASI eksklusif. Hal ini menunjukkan tingginya dukungan keluarga terhadap pemberian ASI eksklusif pada ibu yang memiliki bayi non-ASI eksklusif, hasil ini tidak sejalan dengan pendapat Roesli (2007), menyatakan keluarga merupakan bagian penting dalam keberhasilan atau kegagalan menyusui, karena menentukan kelancaran refleks pengeluaran ASI yang sangat dipengaruhi oleh keadaan emosi dan perasaan ibu. Kesimpulannya belum pasti keluarga dengan dukungan tinggi akan menyebabkan ibu memberikan ASI eksklusif.

Berdasarkan data hasil penelitian disimpulkan bahwa pendidikan pada responden ASIeksklusif yaitu SD, SMP, dan SMA masing-masing sebanyak 7 responden dengan persentase $32 \%$ dan hanya 1 responden yang berpendidikan Perguruan Tinggi dengan persentase 4\% sedangkan pada non-ASI eksklusifberpendidikan terakhir SD dan SMP masing-masing sebanyak 5 responden dengan persentase $45 \%$ dan hanya 1 yang berpendidikan SMA dengan persentase $10 \%$.

Keluarga yang berpendidikan tinggi pengetahuannya baik akan cenderung memberikan dukungan untuk tercapainya ASI eksklusif. Hal ini sesuai dengan pernyataan Maulana (2009), dukungan terbentuk secara bertahap, diawali dari pengetahuan dan pengalaman. Dukungan seseorang terhadap suatu objek menunjukkan pengetahuan orang tersebut terhadap objek yang bersangkutan. Artinya, bahwa mendukung maupun tidak mendukung terbentuk dari komponen pengetahuan. Semakin banyak pengetahuan yang didapatkan akan semakin baik dukungan yang terbentuk. Semakin tahu manfaat ASI eksklusif, dukungan terhadap pemberian ASI eksklusif juga semakin tinggi.

Banyak faktor yang dapat memengaruhi terbentuknya dukungan seseorang, Menurut Wawan dan Dewi (2010), faktor-faktor tersebut diantaranya yaitu pengaruh orang lain yang dianggap penting, pengaruh lembaga pendidikan serta pengaruh kebudayaan. Pengaruh kebudayaan tanpa disadari kebudayaan telah menanamkan pengarah sikap terhadap berbagai masalah. Pengaruh kebudayaan dimana individu hidup dan dibesarkan mempunyai pengaruh besar terhadap status pemberian ASI. Faktor budaya setempat yang memercayai bahwa lebih baik susu formula untuk memenuhi kebutuhan bayi. Dari hasil tersebut dapat dilihat bahwa dukungan keluarga kurang baik dalam mendorong responden untuk memberikan ASI Eksklusif kepada bayinya. Hal ini tidak sejalan dengan penelitian yang dilakukan oleh Santosa (2004) di Kelurahan Padang Bulan Kecamatan Medan Baru bahwa terdapat hubungan dukungan keluarga terhadap pemberian ASI Eksklusif.

\section{Perbedaan Dukungan Keluarga terhadap Ibu yang Memberikan ASI Eksklusif dan Non ASI Eksklusif}

Berdasarkan hasil perhitungan Fisher exact, $\mathrm{P}$ hitung lebih besar dari taraf kesalahan yang ditetapkan $(0,09>0,05)$, maka $\mathrm{H}_{0}$ diterima dan Ha ditolak, maka dapat diartikan bahwa tidak ada perbedaan dukungan keluarga terhadap ibu yang memberikan ASI eksklusif dan non ASI eksklusif di wilayah kerja Puskesmas Sukorame Kota Kediri. Tabulasi antara status pemberian ASI dengan dukungan keluarga terhadap pemberian ASI eksklusif didapatkan 24 responden $(73 \%)$ memiliki dukungan tinggi terhadap pemberian ASI eksklusif. 
Sedangkan 9 responden (27\%) memiliki dukungan rendah terhadap pemberian ASI eksklusif.

Dukungan keluarga dapat dibagi menjadi beberapa dimensi diantaranya, Emotional Support pada ASI eksklusif dengan persentase $73 \%$ sedangkan pada non-ASI eksklusif hanya 27\%.Data ini menunjukkan Emotional Support untuk keluarga dengan ASI eksklusif lebih tinggi daripada non ASI eksklusif. Emotional Support merupakan perasaan nyaman, dihargai, dicintai, dan diperhatikan dengan meyakinkan ibu dengan cara pendekatan dan pemahaman yang membantu ibu menyelesaikan masalah serta mengkomunikasikan kecemasan dan ketakutan mereka untuk memperoleh kenyamanan, simpatik, dan kepedulian. Dapat disimpulkan bahwa tingkat kepedulian keluarga dalam hal memahami dan memberikan kenyamanan kepada ibu lebih tinggi pada ibu yang memberikan ASI eksklusif dibanding non-ASI eksklusif.

Kedua, Cognitive Support pada ASI dengan persentase $74 \%$ sedangkan pada non-ASI eksklusif hanya 26\%. Data ini menunjukkan Cognitive Support untuk keluarga dengan ASI eksklusif lebih tinggi daripada non-ASI eksklusif. Cognitive Support merupakan informasi, pengetahuan, dan nasihat. Dari pengertian tersebut dapat disimpulkan bahwa dalam hal memberikan informasi dan nasihat berdasarkan pengetahuan yang didapatkan sehingga meningkatakan kemampuan menalar dan berpikir mengenai kebaikan ASI bagi bayi untuk pertumbuhan dan perkembangan optimal lebih tinggi keluarga dengan ASI eksklusif daripada non-ASI eksklusif.

Ketiga, Materials Support pada ASI eksklusif dengan persentase $73 \%$ sedangkan pada non-ASI eksklusif hanya 27\%. Data ini menunjukkan Materials Support untuk keluarga dengan ASI eksklusif juga lebih tinggi daripada nonASI eksklusif. Materials Support adalah bantuan atau pelayanan berupa sesuatu barang dalam mengatasi suatu masalah dengan memberikan fasilitas dari satu atau lebih individu yang menyertakan dirinya dalam mendukung tercapainya suatu tujuan. Untuk mewujudkan sebuah tujuan, dapat melalui tindakan atau bantuan yang diberikan. Dukungan nyata atau tindakan yang diberikan kepada ibu akan lebih memberikan dampak positif tercapainya ASI eksklusif, untuk itu sangat diperlukan adanya Materials Support guna mewujudkan ASI eksklusif. Pernyataan Sudiharto (2007) tidak sejalan dengan penelitian yaitu menyatakan bahwa dukungan keluarga mempunyai hubungan dengan suksesnya pemberian ASI Eksklusif kepada bayi. Dukungan keluarga dalam penelitian ini adalah dukungan untuk memotivasi ibu memberikan ASI saja kepada bayinya sampai usia 6 (enam) bulan, memberikan dukungan psikologis kepada ibu dengan mempersiapkan nutrisi yang seimbang kepada ibu. Roesli (2007) berpendapat bahwa, suami dan keluarga dapat berperan aktif dalam pemberian ASI dengan cara memberikan dukungan emosional atau bantuan praktis lainnya.

Pencapaian ASI kurang maksimal mungkin dikarenakan adanya faktorfaktor lain yang mempengaruhi ibu memberikan ASI adalah kurangnya informasi tentang manfaat dan keunggulan ASI, kurangnya pengetahuan ibu tentang upaya mempertahankan kualitas dan kuantitas ASI selama periode menyusui, merasa kurang modern dan menyusui dianggap cara kuno, takut hilangnya kecantikan dan tidak disayang oleh suami serta maraknya iklan perusahaan susu formula di berbagai media masa. Hasil wawancara dengan ibu menyusui di kelurahan Bandar Lor mengatakan bahwa air susu tidak keluar sehingga ibu memberikan susu formula sejak bayi baru lahir. Padahal air susu tidak keluar disebabkan banyak faktor salah satunya karena kurangnya informasi mengenai ASI, apabila dilatih untuk menyusui yaitu memberikan ASI terus 
menerus walau tidak keluar semakin lama akan keluar dengan sendirinya, semakin lama dilatih akan semakin lancar. Masih banyak juga yang beranggapan bahwa susu formula lebih praktis diberikan dari pada ASI saat ibu tidak bersama bayi.

\section{KESIMPULAN}

1. Hampir seluruh responden mempunyai dukungan tinggi terhadap ibu yang memberikan ASI eksklusif.

2. Sebagian besar responden mempunyai dukungan tinggi terhadap ibu yang memberikan nonASI eksklusif.

3. Tidak ada perbedaan dukungan keluarga terhadap ibu yang memberikan ASI eksklusif dan Non ASI eksklusif di Wilayah Kerja Puskesmas Sukorame.

\section{DAFTAR PUSTAKA :}

Ali. 2010. Pengantar Keperawatan Keluarga. Jakarta : EGC.

Dinkes Pemprov Jatim. 2013. Sukseskan Pekan ASI Se-Dunia

http://dinkes.jatimprov.go.id/conten tdetail/9/1/310/dinkes_pemprov_jati m_sukseskan_pekan_asi_sedunia.html Diakses tanggal 1 Maret 2014.

Efendi. 2009. Asuhan Kesehatan Komunitas Teori dan Praktik dalam Keperawatan. Jakarta : Salemba Medika.

Eveline. 2010. Panduan Pintar Merawat bayi dan Balita. Jakarta : PT Wahyu Media.

Hardjito. 2012. Pengantar Biostatistika. Magetan : Forum Ilmiah Kesehatan.

Hidayat. 2007. Metode Penelitian Kebidanan Teknik Analisis Data. Jakarta: Salemba Medika.

Indiarti. 2008. ASI,Susu formula dan Makanan Bayi. Yogyakarta : Elmatera Publishing.

Kian. dkk. 2008. Kajian Lama Pemberian ASI Eksklusif Pada Kelompok Ibu Bekerja Dan Tidak Bekerja Di
Kecamatan Kota Soe Kabupaten Timur Tengah Selatan Tahun 2008. http://isjd.pdii.lipi.go.id/admin/jurn al/1309187195_2085-9341.pdf--1309187195_2085-9341. Diakses tanggal 6 April 2014.

Maryunani. 2007. Inisiasi Menyusui Dini, ASI Eksklusif, dan Manajemen Laktasi. Jakarta: EGC.

Notoatmodjo. 2010. Metodologi Penelitian Kesehatan. Jakarta : Rineka Cipta.

Nugroho. 2010. ASI dan Tumor Payudara. Yogyakarta: Nuha Medika.

Nursalam. 2007. Asuhan Keperawatan pada Pasien Terinfeksi HIV/AIDS. Jakarta: Salemba Medika.

Nursalam. 2008. Konsep dan Penerapan Metodologi Penelitian Ilmu Keperawatan. Jakarta : Salemba Medika.

Nuryanti, dkk. 2009. Faktor-faktor yang Mempengaruhi Pemberian ASI Eksklusif.

http://www.google.com/url?sa=t\&r $\mathrm{ct}=\mathrm{j} \& \mathrm{q}=\&$ esrc $=\mathrm{s} \&$ source $=$ web \&cd $=1 \&$ ved $=0 \mathrm{CCgQFjAA} \&$ url $=\mathrm{http} \%$ 3A\%2F\%2Fjournal.kopertis6.or.id \%2Findex.php\%2Fsosek\%2Farticl e\%2Fdownload\%2F106\%2F86\&ei $=$ Jy9DU9DgLO6tiQfR04GoBg\&u sg=AFQjCNFkLDQkb0VWxNJd XOBv0S5PX8GpUQ\&bvm=bv.64 367178,d.aGc Diakses tanggal 6 April 2014.

Proverawati. 2010. Kapita Selekta ASI \& Menyusui. Yogyakarta: Nuha Medika.

Rahayu, dkk. 2013. Pedoman Ujian Akhir Program (UAP) Jurusan kebidanan Poltekkes Malang. Kediri : Prodi Kebidanan Kediri.

Roesli. 2005. Mengenal ASI Eksklusif. Jakarta: Trubus Agriwidya.

Rosita. 2008. ASI Untuk Kecerdasan Bayi. Yogyakarta: Ayyana. ISugiyono. 2012. Statistika untuk Penelitian. Bandung : ALFABETA. 
Sugono, dkk. 2008. Kamus Besar Bahasa Indonesia Pusat Bahasa Edisi Keempat. Jakarta : Gramedia Pustaka Utama.

Sunaryo. 2004. Psikologi Untuk Keperawatan. Jakarta : EGC.

Suprajitno. 2004. Asuhan Keperawatan Keluarga Aplikasi dalam Pektek. Jakarta : EGC.

Syafrudin. 2010. Sosial Budaya Dasar untuk Mahasiswa Kebidanan. Jakarta : Trans Info Media.

Tanjung. 2010. Pedoman Penulisan Karya Ilmiah (Proposal, Skripsi dan Tesis). Jakarta : KENCANA.

Wawan, dkk. (2010). Teori dan pengukuran pengetahuan, sikap dan perilaku manusia. Yogyakarta: Nuha Medika.

Yuliarti. 2010. Keajaiban ASI Makanan Terbaik Untuk Kesehatan, Kecerdasan, dan Kelincahan Si Kecil. Yogyakarta : Andi. 